\title{
Pengaruh Etika Birokrasi dan Kinerja Pegawai Terhadap Kualitas Pelayanan Publik Kantor Camat di Kota Bitung
}

\author{
Michel J.N. Potolau1) \\ 1) Program Studi Manajemen, Fakultas Ekonomi, Universitas Sariputra Indonesia Tomohon
}

Diterima Februari 2020; Disetujui April, 2020; Dipublikasikan Juni , 2020

\begin{abstract}
Abstrak
Tujuan dari penelitian ini untuk mengetahui pengaruh Etika Birokrasi secara langsung dan tidak langsung terhadap Kualitas Pelayanan Publik, pengaruh Kinerja Pegawai secara langsung dan tidak langsung terhadap Kualitas Pelayanan Publik, pengaruh secara simultan Etika Birokrasi dan Kinerja Pegawai terhadap Kualitas Pelayanan Publik. Metode penelitian yang digunakan adalah metode kuantitatif. Analisis data yang digunakan yaitu path analisis: $\mathrm{Y}=\rho \mathrm{yx} 1 \mathrm{X} 1+\rho \mathrm{yx} 2 \mathrm{X} 2+\rho \mathrm{y} \epsilon$. Hasil analisis data: nilai signifikan Etika Birokrasi sebesar $0.021<0.05$, nilai signifikan Kinerja Pegawai sebesar 0.02<0.05, dan nilai signifikan Etika Birokrasi dan Kinerja Pegawai sebesar $0.001<0.05$, R square 0.284 (28.4\%), hasil analisis path: pengaruh langsung X1 terhadap Y sebesar $0.104(10.4 \%)$, pengaruh tidak langsung X1 terhadap Y melalui X2 sebesar 0.036 (3.6\%), pengaruh langsung X2 terhadap Y sebesar 0.104 (10.4\%), pengaruh tidak langsung X2 terhadap Y melalui X1 sebesar 0.036 (3.6\%) dan pengaruh variabel lain terhadap Y sebesar 0.715 (71.5\%). Simpulan dari penelitian ini adalah terdapat pengaruh Etika Birokrasi (X1) terhadap Kualitas Pelayanan Publik (Y), terdapat pengaruh Kinerja Pegawai (X2) terhadap Kualitas Pelayanan Publik (Y), secara bersama-sama Etika Birokrasi (X1) dan Kinerja Pegawai (X2) berpengaruh terhadap Kualitas Pelayanan Publik (Y).
\end{abstract}

Kata Kunci: Etika, Kinerja, Kualitas Pelayanan

\section{Abstract}

The purpose of this study is to determine the effect of bureaucratic ethics directly and indirectly on the quality of public services, the effect of employee performance directly and indirectly on the quality of public services, the effect of simultan's bureaucratic ethics and employee performance on the quality of public services. The research method used is a method quantitative. Analysis of the data used is the path analysis: $Y=\rho y x 1 X 1+\rho y x 2 X 2+\rho y \epsilon$. The results of data analysis: the significant value of Bureaucracy Ethics by $0.021<0.05$, the significant value of Employee Performance by $0.02<0.05$, and the significant value of Bureaucracy Ethics and Employee Performance by 0.001 $<0.05$, $R$ square 0.284 (28.4\%), the results of path analysis: the direct effect of X1 on $Y$ was 0.104 (10.4\%), the indirect effect of X1 on Y through X2 was 0.036 (3.6\%), the direct effect of X2 on Y was 0.104 (10.4\%), the indirect effect of X2 on $Y$ through $X 1$ was 0.036 (3.6\%) and the influence of other variables on $Y$ by 0.715 (71.5\%). The conclusion of this study is that there is an influence of Bureaucracy Ethics (X1) on Public Service Quality (Y), there is an influence of Employee Performance (X2) on Public Service Quality (Y), together with Bureaucracy Ethics (X1) and Employee Performance (X2) affect the Quality of Public Services (Y).

Keywords: Ethics, Performance, Service Quality

How to Cite: Potolau, N.J.M. (2020). Pengaruh Etika Birokrasi dan Kinerja Pegawai Terhadap Kualitas Pelayanan Publik Kantor Camat di Kota Bitung. PUBLIKAUMA: Jurnal Ilmu Administrasi Publik UMA, Vol 8 (1): $1-10$

${ }^{*}$ Corresponding author: ISSN 2549-9165 (Print)

E-mail: potolaumichel@gmail.com ISSN 2580-2011 (Online) 


\section{PENDAHULUAN}

Kualitas Pelayanan Publik menurut Kepmen PAN No.63/KEP/M.PAN/7/2003 merupakan segala kegiatan pelayanan yang dilaksanakan oleh penyelenggara Kualitas Pelayanan Publik sebagai upaya pemenuhan kebutuhan penerima layanan, maupun dalam rangka pelaksanaan ketentuan peraturan perudang-undangan.

Pelayanan yang terkait dengan prinsipprinsip good govermant sebagaimana tuntutan reformasi yaitu mewujudkan clean government dalam penyelenggaraan Negara yang didukung dengan asas-asas umum pemerintahan yang baik yaitu asas kepastian hukum, asas tertib penyelenggaraan Negara, asas kepentingan umum, asas keterbukaan, asas proporsionalitas, asas profesionalitas dan asas akuntabilitas. Kualitas Pelayanan Publik menurut Sinambela (2011:5) adalah setiap kegiatan yang dilakukan oleh pemerintah terhadap sejumlah manusia yang memiliki setiap kegiatan yang menguntungkan dalam suatu kumpulan atau kesatuan, dan menawarkan kepuasan meskipun hasilnya tidak terikat pada suatu produk secara fisik. Karena itu, tugas utama dalam rangka penguatan eksistensi pemerintah, termasuk pemerintah daerah adalah untuk menciptakan pemerintahan yang secara politik akseptabel, secara hukum efektif dan secara administratif efesien.

Dalam rangka pencapaian kualitas pelayanan yang baik (pelayanan prima) kepada masyarakat, dipengaruhi oleh berbagai faktor di antaranya Etika Birokrasi, Darwin dalam Bisri M.H (2019) mengartikan Etika Birokrasi sebagai seperangkat nilai yang menjadi acuan atau penuntun bagi tindakan manusia dalam organisasi publik. Hasil penelitian dari Pai F.P (2016) menjelaskan bahwa belum optimalnya profesionalitas Kualitas Pelayanan Publik oleh aparatur birokrasi disebabkan antara lain kurangnya pemahaman, penghayatan dan pengamalan aparatur birokrasi terhadap nilai-nilai atau norma-norma Etika Birokrasi, sehingga Etika Birokrasi dapat memberikan pengaruh terhadap Kualitas Pelayanan Publik.

Etika Birokrasi memberikan berbagai asas etis, ukuran baku, pedoman perilaku, dan kebajikan moral yang dapat diterapkan oleh setiap aparat birokrasi guna terselenggaranya tugas-tugas pemerintahan yang baik bagi kepentingan publik. Etika Birokrasi berusaha menentukan norma-norma mengenai yang seharusnya dilakukan oleh setiap aparat birokrasi dalam melaksanakan fungsinya dan memegang jabatannya. Etika administrasi/birokrasi publik berwujud seperti: kode etik aparatur birokrasi/PNS atau etika jabatan PNS, sumpah jabatan PNS, dan lain-lain (Keban dalam Pai F.P, 2016)

Secara logis isu etika menjadi sangat vital di dalam administrasi publik karena adanya keleluasaan atau diskresi yang diberikan kepada para eksekutif, Diskresi administrasi menjadi "strating point" bagi masalah moral atau etika dalam dunia administrasi publik. Memang, masalah moral atau etika jauh lebih memprihatinkan dan lebih fatal akibatnya dibandingkan dengan kesalahan manusia yang dilakukan dalam pemerintahan. Etika dapat menjadi suatu faktor yang mensukseskan tetapi juga sebaliknya menjadi pemicu dalam menggagalkan tujuan kebijakan, struktur organisasi dan manajemen publik.

Bila moralitas para penyusun serta pelaksana kebijakan publik rendah, maka kualitas kebijakan yang dihasilkanpun sangat rendah. Begitu juga bila struktur organisasi publik yang disusun berdasarkan kepentingankepentingan tertentu yang berbeda dengan kepentingan-kepentingan publik, maka struktur organisasi tersebut tidak akan efektif. Di dalam proses manajemen misalnya, kebobrokan moralitas atau etika dari mereka yang merencanakan, mengimplementasikan, dan memonitor, serta mengevaluasi Kualitas Pelayanan Publik akan sangat berpengaruh pada hasil akhir, dengan kata lain tingkat moralitas atau etika para pemberi Kualitas Pelayanan Publik akan mempengaruhi pencapaian hasil.

Faktor selanjutnya yang mempengaruhi dalam pelayanan kepada masyarakat (Kualitas Pelayanan Publik) adalah Kinerja Pegawai, Sinambela dalam Sasti E.W (2105) mendefinisikan "Kinerja Pegawai sebagai kemampuan pegawai dalam melakukan sesuatu dengan keahlian tertentu. Kinerja sebagai kemampuan dan keterampilan para pegawai dalam memenuhi atau menyelesaikan 
seluruh pekerjaan. Pegawai yang mempunyai kompetensi dalam menyelesaikan pekerjaan merupakan pegawai yang memiliki kontribusi kinerja yang baik, yang akan berdampak pada Kualitas Pelayanan Publik yang prima hal ini sejalan dengan hasil penelitian dari Supit T.J. (2015) yang menyatakan bahwa Kinerja Pegawai berpengaruh secara signifikan terhadap kualitas pelayanan. Dengan demikian penyelenggaraan pemerintahan dalam pelayanan yang baik (pelayanan prima) kepada masyarakat akan tercapai apabila para pegawai dalam suatu organisasi pemerintahan (birokrassi) memiliki etika dan kinerja yang baik.

Namun pada kenyataanya pelayanan prima belum terlaksana secara maksimal karena disebabkan oleh berbagai masalah di antaraya Etika Birokrasi dan Kinerja Pegawai yang belum sesuai dengan apa yang diharapkan. Kenyataan itupun saat ini dialami oleh Pemerintah Kota Bitung dalam hal ini pegawai Kantor Camat yang ada di Kota Bitung yang merupakan salah satu penyelenggara kebijakan pemerintahan Kota Bitung. Di mana dalam melaksanakan tugas melayani kebutuhan masyarakat diperhadapkan pada berbagai masalah di antaranya:

Etika Birokrasi dalam hal ini pelaksanaan tugas Kualitas Pelayanan Publik belum menampakan profesionalitas dan itu tercermin dalam pelaksanaan tugas seharihari, di mana masi ada pegawai yang tidak berada di kantor pada saat jam kerja dan bukan karena tugas luar, ada beberapa pegawai yang sering terlambat pada saat masuk kantor, respon yang kurang bersahabat dari pegawai dalam menanggapi keluhan masyarakat.

Kemudian masalah Kinerja Pegawai yang belum maksimal, di mana masih belum terbukanya informasi dan kurangnya kejelasan informasi yang diberikan kepada masyarakat di antaranya ketika ada keputusan pemerintah untuk memberikan bantuan kepada masyarakat, masih ada masyrakat yang belum/tidak tahu, ketika ada keputusan pemerintah dalam perubahan syarat mengurus administrasi, masih ada masyarakat yang belum tahu tentang syarat mengurus adaministrasi yang berhungan dengan kebutuhan masyarakat, dan ini akibat dari kurang dan lambatnya sosialisai kepada masyarakat dan ini merupakan bagian dari Kinerja Pegawai. Kemampuan pegawai dalam meyelesaikan pekerjaan masih kurang di mana masih ada pegawai yang belum menguasai teknologi (komputer), sering menunda pekerjaan yang menyebabkan Kualitas Pelayanan Publik menjadi tidak efektif dan efisien.

Berdasarkan uraian latar belakang masalah, maka tujuan dalam penelitian ini adalah untuk mengetahui seberapa besar pengaruh Etika Birokrasi terhadap Kualitas Pelayanan Publik, untuk mengetahui seberapa besar pengaruh Kinerja Pegawai terhadap Kualitas Pelayanan Publik dan untuk mengetahui seberapa besar pengaruh Etika Birokrasi dan Kinerja Pegawai terhadap Kualitas Pelayanan Publik Kantor Camat di Kota Bitung.

\section{METODE PENELITIAN}

Hipotesis dalam penelitian ini adalah terdapat pengaruh langsung dan tidak langsung Etika Birokrasi terhadap Kualitas Pelayanan Publik, terdapat pengaruh langsung dan tidak langsung Kinerja Pegawai terhadap Kualitas Pelayanan Publik dan secara bersamasama Etika Birokrasi dan Kinerja Pegawai berpengaruh terhadap Kualitas Pelayanan Publik. Metode yang digunakan dalam penelitian ini adalah metode kuantitatif. (Sugiono, 2016) metode kuantitatif adalah metode penelitian yang berlandaskan pada filsafat positivisme (Tidak mengenal adanya spekulasi, semua didasarkan pada data empiris), digunakan untuk meneliti pada populasi atau sampel tertentu, pengumpulan data menggunakan instrumen penelitian, analisis data bersifat kuantitatif/statistik, dengan tujuan untuik menguji hipotesis yang telah ditetapkan. Populasi dalam penelitian ini adalah seluruh pegawai yang ada di 8 (delapan) Kantor Camat di Kota Bitung yang berjumlah 130 orang, Sampel dalam penelitian ini adalah pegawai Kantor Camat Girian, Kantor Camat Madidir, dan Kantor Camat Aertembanga dengan jumlah pegawai keseluruhan 48 orang menggunakan teknik cluster random sampling. (Margono, 2004) teknik ini digunakan bilamana populasi tidak terdiri dari individu-individu, melainkan terdiri dari kelompok-kelompok individu atau 
cluster. Teknik sampling daerah ini sering digunakan melalui dua tahap, yaitu tahap pertama menentukan sampel daerah, dan tahap berikutnya menentukan orang-orang yang ada pada daerah itu secara sampling juga. Teknik ini dapat digambarkan di bawah ini.

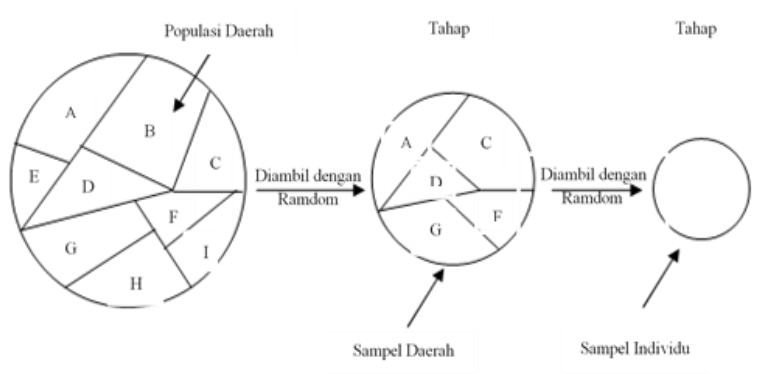

Dalam penelitian ini populasi daerah yaitu seluruh Kecamatan yang ada di Kota Bitung berjumlah 8 Kecamatan dipilih dengan random menjadi 3 Kecamatan yaitu Kantor Camat Madidir, Kantor Camat Girian dan Kantor Camat Aertembaga, deipilih dengan ramdom individu yang ada di 3 Kecamatan tersebut sehingga mendapatkan sampel.

Variabel dalam penelitian ini adalah Variabel independen yaitu: Etika Birokrasi (X1) dan Kinerja Pegawai (X2), sedangkan Variabel dependen (Y) yaitu: Kualitas Pelayanan Publik. Teknik pengumpulan data dalam penelitian ini melalui: Observasi/survey, Wawancara, dan Angket/kuesioner. Instrumen penelitian berbentuk angket atau kuesioner. Penelitian ini menggunakan uji analisis path (analisis jalur) dengan diagram jalur sebagai berikut:

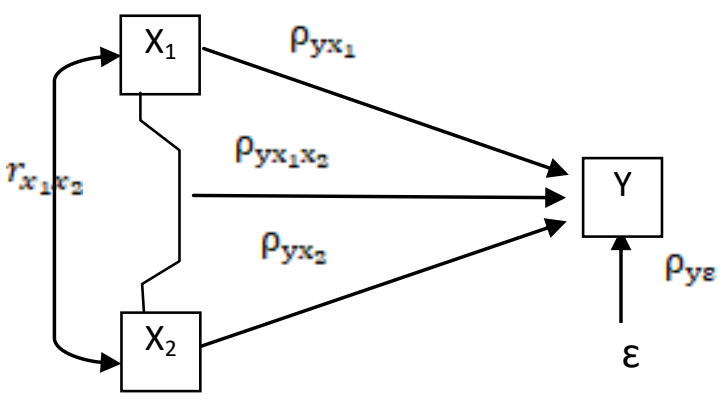

Gambar 1: Diagram Jalur Analasis Path

HASIL DAN PEMBAHASAN

Uji Validitas Instrumen

Isntrumen Variabel Etika Birokrasi

Tabel 1. Koefisien Validitas Item Variabel Etika Birokrasi

\begin{tabular}{cccc}
\hline $\begin{array}{c}\text { No } \\
\text { Item }\end{array}$ & r hitung & r tabel & Keterangan \\
\hline 1 & 0.490 & 0.285 & Valid \\
\hline 2 & 0.608 & 0.285 & Valid \\
\hline 3 & 0.383 & 0.285 & Valid \\
\hline 4 & 0.689 & 0.285 & Valid \\
\hline 5 & 0.428 & 0.285 & Valid \\
\hline 6 & 0.407 & 0.285 & Valid \\
\hline 7 & 0.366 & 0.285 & Valid \\
\hline 8 & 0.561 & 0.285 & Valid \\
\hline 9 & 0.348 & 0.285 & Valid \\
\hline 10 & 0.563 & 0.285 & Valid \\
\hline 11 & 0.642 & 0.285 & Valid \\
\hline 12 & 0.593 & 0.285 & Valid \\
\hline 13 & 0.397 & 0.285 & Valid \\
\hline
\end{tabular}

Sumber hasil uji dengan SPSS

Pengujian validitas dilakukan dengan cara membandingkan skor $r$ hitung dengan $r$ tabel ( $\mathrm{r}$ tabel $=0.285$, dengan $a=0.05$, maka $\mathrm{N}$ $=48-2$ ). Apabila nilai $r$ hitung $>r$ tabel, maka item tersebut dinyatakan valid. Berdasarkan data yang ada, diperoleh hasil uji validitas pada 22 pertanyaan, yaitu 13 pertanyaan valid.

Instrumen Variabel Kinerja Pegawai

Tabel 2. Koefisien Validitas Item Variabel Kinerja Pegawai

\begin{tabular}{cccc}
\hline $\begin{array}{c}\text { No } \\
\text { Item }\end{array}$ & r hitung & r tabel & Keterangan \\
\hline 1 & 0.534 & 0.285 & Valid \\
\hline 2 & 0.494 & 0.285 & Valid \\
\hline 3 & 0.489 & 0.285 & Valid \\
\hline 4 & 0.396 & 0.285 & Valid \\
\hline 5 & 0.344 & 0.285 & Valid \\
\hline 6 & 0.516 & 0.285 & Valid \\
\hline 7 & 0.395 & 0.285 & Valid \\
\hline 8 & 0.432 & 0.285 & Valid \\
\hline 9 & 0.313 & 0.285 & Valid \\
\hline 10 & 0.545 & 0.285 & Valid \\
\hline 11 & 0.352 & 0.285 & Valid \\
\hline 12 & 0.358 & 0.285 & Valid \\
\hline 13 & $.593^{* *}$ & 0.285 & Valid \\
\hline 14 & $.326^{*}$ & 0.285 & Valid \\
\hline 15 & $.309^{*}$ & 0.285 & Valid \\
\hline 16 & $.389^{* *}$ & 0.285 & Valid \\
\hline Sumber: Hasil uji dengan SPSS &
\end{tabular}


Pengujian validitas dilakukan dengan cara membandingkan skor $r$ hitung dengan $r$ tabel ( $\mathrm{r}$ tabel $=0.285$ ), dengan $\alpha=0.05, \mathrm{~N}=48$ 2). Apabila nilai $r$ hitung $>$ dari $r$ tabel, maka item tersebut dinyatakan valid. Berdasarkan data yang ada, diperoleh hasil uji validitas pada 23 pertanyaan, yaitu 16 pertanyaan valid.

Instrumen Variabel Kualitas Pelayanan Publik

Tabel 3. Koefisien Validitas Item Variabel Kualitas Pelayanan Publik

\begin{tabular}{llll}
\hline $\begin{array}{l}\text { No } \\
\text { Item }\end{array}$ & r hitung & r tabel & Keterangan \\
\hline 1 & 0.460 & 0.285 & Valid \\
\hline 2 & 0.543 & 0.285 & Valid \\
\hline 3 & 0.598 & 0.285 & Valid \\
\hline 4 & 0.589 & 0.285 & Valid \\
\hline 5 & 0.534 & 0.285 & Valid \\
\hline 6 & 0.591 & 0.285 & Valid \\
\hline 7 & 0.504 & 0.285 & Valid \\
\hline 8 & 0.523 & 0.285 & Valid \\
\hline 9 & 0.665 & 0.285 & Valid \\
\hline 10 & 0.315 & 0.285 & Valid \\
\hline 11 & 0.522 & 0.285 & Valid \\
\hline 12 & 0.441 & 0.285 & Valid \\
\hline 13 & 0.548 & 0.285 & Valid \\
\hline 14 & 0.472 & 0.285 & Valid \\
\hline 15 & 0.460 & 0.285 & Valid \\
\hline 16 & 0.582 & 0.285 & Valid \\
\hline 17 & 0.332 & 0.285 & Valid \\
\hline 18 & 0.455 & 0.285 & Valid \\
\hline 19 & 0.519 & 0.285 & Valid \\
\hline
\end{tabular}

Sumber hasil uji dengan SPSS.

Pengujian validitas dilakukan dengan cara membandingkan skor $r$ hitung dengan $r$ tabel $(\mathrm{r}$ tabel $=0.285)$, dengan $=0.05, \mathrm{~N}=48$ 2). Apabila nilai $r$ hitung $>$ dosi $r$ tabel, maka item tersebut dinyatakan valid, Berdasarkan data yang ada, diperoleh hasil uji validitas pada 23 pertanyaan, yaitu 19 pertanyaan valid.

\section{Uji Reliabilitas Instrumen}

Uji reliabilitas instrumen bertujuan untuk mengetahui besarnya indeks instrument dari variabel, dengan menggunakan rumus Cronbach's Alpha pada program SPSS 16.0, keputusan untuk mengetahui bahwa instrumen reliabel jika nilai koefisien reliabilitas $>0,6$.
Tabel 4. Hasil Uji Reliabilitas Instrumen

\begin{tabular}{llll}
\hline No & Variabel & $\begin{array}{l}\text { Koefisien } \\
\text { reliabilitas }\end{array}$ & Keterangan \\
\hline 1 & $\begin{array}{l}\text { Etika } \\
\text { Birokrasi }\end{array}$ & 0,66 & Reliabel \\
\hline 2 & $\begin{array}{l}\text { Kinerja } \\
\text { Pegawai }\end{array}$ & 0,653 & Reliabel \\
\hline 3 & $\begin{array}{l}\text { Kualitas } \\
\text { Pelayanan }\end{array}$ & 0,822 & Reliabel \\
& Publik & \\
\hline Sumber: Hasil uji dengan SPSS &
\end{tabular}

Dari hasil uji reliabilitas instrumen menunjukan bahwa ketiga variabel yaitu Etika Birokrasi, Kinerja Pegawai dan Kualitas Pelayanan Publik adalah reliabel karena nilai koefisien reliabilitas $>0,6$.

\section{Analisis Data \\ Analisis Korelasi}

Tabel 5. Hasil Analisis Korelasi

\begin{tabular}{|c|c|c|c|c|}
\hline \multicolumn{5}{|c|}{ Correlations } \\
\hline & & $\begin{array}{l}\text { Etika } \\
\text { Birokrasi }\end{array}$ & $\begin{array}{l}\text { Kinerja } \\
\text { Pegawai }\end{array}$ & $\begin{array}{l}\text { Kualitas } \\
\text { Pelayanan } \\
\text { Publik }\end{array}$ \\
\hline \multirow[t]{3}{*}{$\begin{array}{l}\text { Etika } \\
\text { Birok } \\
\text { rasi }\end{array}$} & $\begin{array}{l}\text { Pearson } \\
\text { Correlati } \\
\text { on }\end{array}$ & 1 & $0.353^{*}$ & $0.438^{* *}$ \\
\hline & $\begin{array}{l}\text { Sig. }(2- \\
\text { tailed) }\end{array}$ & & 0.014 & 0.002 \\
\hline & $\mathrm{N}$ & 48 & 48 & 48 \\
\hline \multirow{3}{*}{$\begin{array}{l}\text { Kiner } \\
\text { ja } \\
\text { Pega } \\
\text { wai }\end{array}$} & $\begin{array}{l}\text { Pearson } \\
\text { Correlati } \\
\text { on }\end{array}$ & $0.353^{*}$ & 1 & $0.439^{* *}$ \\
\hline & $\begin{array}{l}\text { Sig. } \\
\text { tailed })\end{array}$ & 0.014 & & 0.002 \\
\hline & $\mathrm{N}$ & 48 & 48 & 48 \\
\hline \multirow{3}{*}{$\begin{array}{l}\text { Kuali } \\
\text { tas } \\
\text { Pelay } \\
\text { anan } \\
\text { Publi } \\
\text { k }\end{array}$} & $\begin{array}{l}\text { Pearson } \\
\text { Correlati } \\
\text { on }\end{array}$ & $0.438^{* *}$ & $0.439^{* *}$ & 1 \\
\hline & $\begin{array}{l}\text { Sig. } \\
\text { tailed })\end{array}$ & 0.002 & 0.002 & \\
\hline & $\mathrm{N}$ & 48 & 48 & 48 \\
\hline \multicolumn{5}{|c|}{$\begin{array}{l}\text { *. Correlation is significant at the } 0.05 \text { level (2- } \\
\text { tailed). }\end{array}$} \\
\hline
\end{tabular}

Sumber : Hasil analisis dengan SPSS

Dari hasil analisis diketahui nilai Sig. (2tailed) antara Etika Birokrasi (X1) dan Kualitas Pelayanan Publik (Y) sebesar $0.002<0.005$, dan nilai $r$ hitung antara Etika Birokrasi (X1) dan Kualitas Pelayanan Publik (Y) sebesar 
$0.438>\mathrm{r}$ tabel 0.284 , hasil ini mengartikan bahwa terdapat korelasi yang signifikan antara variabel Etika Birokrasi dan variabel Kualitas Pelayanan Publik, dengan kata lain semakin meningkatnya Etika Birokrasi, maka akan meningkat pula Kualitas Pelayanan Publik.

Nilai Sig. (2-tailed) antara Kinerja Pegawai (X2) dan Kualitas Pelayanan Publik (Y) sebesar $0.002<0.05$, dan nilai $r$ hitung antara Kinerja Pegawai (X2) dan Kualitas Pelayanan Publik (Y) sebesar $0.439>\mathrm{r}$ tabel 0.284 , hasil ini mengartikan bahwa terdapat korelasi antara variabel Kinerja Pegawai dan variabel Kualitas Pelayanan Publik, dengan kata lain semakin meningkatnya Kinerja Pegawai akan meningkat pula Kualitas Pelayanan Publik Nilai Sig. (2-tailed) antara Etika Birokrasi dan Kinerja Pegawai sebesar $0.014<0.05$ dengan nilai correlation 0.353 ini mengartikan bahwa ada korelasi antara variabel Etika Birokrasi dan Kinerja Pegawai yang secara tidak langsung saling berpengaruh terhadap Kualitas Pelayanan Publik, dimana Etika Birokrasi berpengaruh tidak langsung terhadap Kualitas Pelayanan Publik melalui Kinerja Pegawai dan sebaliknya KInerja Pegawai berpengaruh tidak langsung terhadap Kualitas Pelayanan Publik melalui Etika Birotkrasi.

\section{Uji t}

Uji $t$ dilakukan untuk mengetahui pengaruh dari masing-masing variabel independen secara parsial terhadap variabel dependen, dengan membandingkan hasil $t$ hitung dan $t$ tabel. Jika $t$ hitung $>$ dari $t$ tabel, maka terdapat pengaruh variabel independen terhadap variabel dependen, kemudian dengan membandingkan nilai signifikan, jika nilai signifikan < 0.05, maka terdapat pengaruh variabel independen terhadap variabel dependen.

Tabel 6. Hasil Uji t

\begin{tabular}{|c|c|c|c|c|c|c|}
\hline \multicolumn{7}{|c|}{ Coefficients(a) } \\
\hline & \multirow{2}{*}{ Model } & \multicolumn{2}{|c|}{$\begin{array}{l}\text { Unstandardize } \\
\text { d Coefficients }\end{array}$} & \multicolumn{3}{|c|}{$\begin{array}{c}\text { Standardized } \\
\text { Coefficients }\end{array}$} \\
\hline & & B & $\begin{array}{l}\text { Std. } \\
\text { Error }\end{array}$ & Beta & $\mathrm{t}$ & Sig. \\
\hline \multirow{3}{*}{1} & $\begin{array}{c}\text { (Consta } \\
n t)\end{array}$ & $\begin{array}{c}13.75 \\
3 \\
\end{array}$ & $\begin{array}{c}17.12 \\
5 \\
\end{array}$ & & $\begin{array}{c}0.80 \\
3 \\
\end{array}$ & $\begin{array}{c}0.42 \\
6 \\
\end{array}$ \\
\hline & $\begin{array}{c}\text { Etika } \\
\text { Birokras } \\
\text { i } \\
\end{array}$ & 0.373 & 0.155 & $\begin{array}{c}0.32 \\
3\end{array}$ & $\begin{array}{c}2.39 \\
7\end{array}$ & $\begin{array}{c}0.02 \\
1\end{array}$ \\
\hline & Kinerja & 0.404 & 0.168 & 0.32 & 2.40 & 0.02 \\
\hline
\end{tabular}

\begin{tabular}{|l|l|l|l|l|l|}
\hline Pegawai & & & 4 & 5 & \\
\hline \multicolumn{6}{|c|}{ a. Dependent Variable: Kualitas Pelayanan Publik } \\
\hline
\end{tabular}
Sumber: Hasil uji dengan SPSS

Data tabel 6 menunjukan bahwa t hitung variabel Etika Birokrasi 2.397 dan t hitung Kinerja Pegawai 2.405 dgn t tabel 2.0141 (a/2;n-k-1), dengan nilai signivikan variabel Etika Birokrasi 0.021 dan variabel Kinerja Pegawai 0.02, $\alpha=0.05$ Hasil ini menujukan bahwa t hitung variabel Etika Birokrasi 2.397 dan t hitung variabel Kinerja Pegawai $2.405>t$ tabel 2.0141, dengan nilai signivikan variabel Etika Birokrasi $0.021<0.05$ dan variabel Kinerja Pegawai $0.02<0.05$, mengartikan bahwa terdapat pengaruh signivikan variabel Etika Birokrasi terhadap Kualitas Pelayanan Publik dan terdapat pengaruh signivikan variabel Kinerja Pegawai terhadap Kualitas Pelayanan Publik. Hasil ini menunjukan jika Etika Birokrasi mengalami peningkatan, maka Kualita Pelayanan Publik juga akan meningkat, demkian pula jika Kinerja Pegawai mengalami peningkatan, maka Kualitas Pelayanan Publik juga akan meningkat.

Uji F

Uji F dilakukan untuk menguji pengaruh semua variabel independen secara serentak atau bersama-sama terhadap variabel dependen, dengan membandingkan hasil $f$ hitung dan $\mathrm{f}$ tabel. Jika f hitung $>\mathrm{f}$ tabel, terdapat pengaruh secara simultan variabel independen terhadap variabel dependen, kemudian dengan membandingkan nilai signifikan, jika nilai signifikan $<0.05$, maka terdapat pengaruh secara simultan variabel independen terhadap variabel dependen.

Tabel 7. Uji F

\begin{tabular}{|l|l|l|l|l|l|}
\hline \multicolumn{7}{|l|}{ ANOVA $^{\mathrm{b}}$} & $\begin{array}{l}\text { Sum of } \\
\text { Squares }\end{array}$ & df & $\begin{array}{l}\text { Mean } \\
\text { Square }\end{array}$ & F & Sig. \\
\hline $\begin{array}{l}\text { Regressio } \\
\mathrm{n}\end{array}$ & 466.478 & 2 & 233.239 & $\begin{array}{l}8.91 \\
9\end{array}$ & $\begin{array}{l}0.001 \\
\mathrm{a}\end{array}$ \\
\hline Residual & 1176.772 & 45 & 26.150 & & \\
\hline Total & 1643.250 & 47 & & & \\
\hline $\begin{array}{l}\text { a. Predictors: (Constant), Kinerja Pegawai, Etika } \\
\text { Birokrasi }\end{array}$ \\
$\begin{array}{l}\text { b. Dependent Variable: Kualitas Pelayanan } \\
\text { Publik }\end{array}$ \\
\hline
\end{tabular}

Sumber: Hasil uji dengan SPSS 
Data tabel 7 menunjukan bahwa f hitung 8.919 dan $\mathrm{f}$ tabel 3.20 (k;n-k). dengan nilai signivikasi $0.001, \alpha=0.05$. Hasil ini menunjukan bahwa f hitung $8.919>\mathrm{f}$ tabel 3.20 dan nilai signivikan $0.001<0.05$. Mengartikan bahwa terdapat pengaruh secara simultan variabel Etika Birokrasi dan Kinerja Pegawai terhadap Kualitas Pelayanan Publik. Dengan kata lain bahwa peningkatan Kualitas Pelayanan Publik akan dipengaruhi oleh peningkatan Etika Birokrasi dan Kinerja Pegawai.

Analisis Path (Jalur)

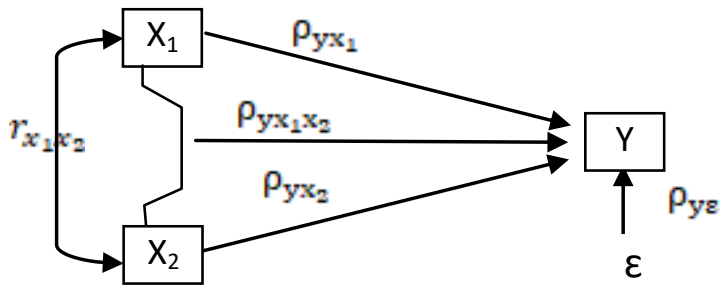

Gambar 3. Diagram Jalur $\mathrm{X}_{1} \mathrm{X}_{2}$ Terhadap $\mathrm{Y}$

Keterangan :

$\mathrm{X}_{1} \quad$ : Etika Birokrasi

$\mathrm{X}_{2} \quad$ : Kinerja Pegawai

Y : Kualitas Pelayanan Publik

$\varepsilon \quad$ : Residual variabel atau variabel lain

$r_{x_{1} x_{2}}$ : Koefisien korelasi yang di tunjukan antara $\mathrm{X}_{1}$ dan $\mathrm{X}_{2}$

$\rho_{\mathrm{yx}_{1}} \quad$ : Pengaruh $\mathrm{X}_{1}$ terhadap $\mathrm{Y}$

$\rho_{y_{x}} \quad$ : Pengaruh $X_{2}$ terhadap $Y$

$\rho_{\mathrm{yx}_{1} \mathrm{x}_{\mathrm{z}}}$ :Secara simultan $\mathrm{X}_{1}$ dan $\mathrm{X}_{2}$

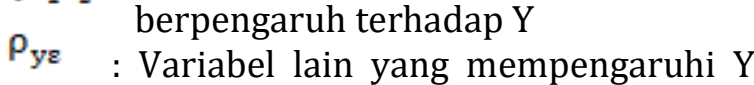
(Kualitas Pelayanan Publik)

Koefisien Determinasi (R Square) Tabel 8. Koefisien Determinasi (R Square)

\begin{tabular}{|l|c|l|l|l|}
\hline \multicolumn{5}{|c|}{ Model Summary } \\
\hline Model & $\mathrm{R}$ & $\begin{array}{c}\mathrm{R} \\
\text { Square }\end{array}$ & $\begin{array}{l}\text { Adjusted } \\
\text { R Square }\end{array}$ & $\begin{array}{c}\text { Std. Error of } \\
\text { the Estimate }\end{array}$ \\
\hline 1 & $\begin{array}{l}0.533 \\
\mathrm{a}\end{array}$ & 0.284 & 0.252 & 5.11375 \\
\hline
\end{tabular}

a. Predictors: (Constant), Kinerja Pegawai, Etika Birokrasi

Sumber: Hasil analisis dengan SPSS

Data tabel 8 menunjukan koefisien determinasi ( $\mathrm{R}$ Square), diketahui bahwa secara bersama-sama variabel Etika Birokrasi dan Kinerja Pegawai memberikan kontribusi (pengaruh) sebesar 0.284 atau $28.4 \%$ terhadap Kualitas Pelayanan Publik, sementara sisanya $71,6 \%$ merupkan kontribusi dari variabel-variabel lain yang tidak dimasukan dalam penelitian ini. Dengan demikian jalur $\varepsilon$ (variabel residu atau variabel lain yang tidak diteliti) adalah :

$$
\begin{gathered}
\rho_{y s}=\sqrt{(1-0.284)}=0.846 \\
\text { Berdasarkan data di atas dapat di }
\end{gathered}
$$

ketahui kontribusi jalur dari masing-masing variabel dalam bentuk diagram jalur berikut ini:

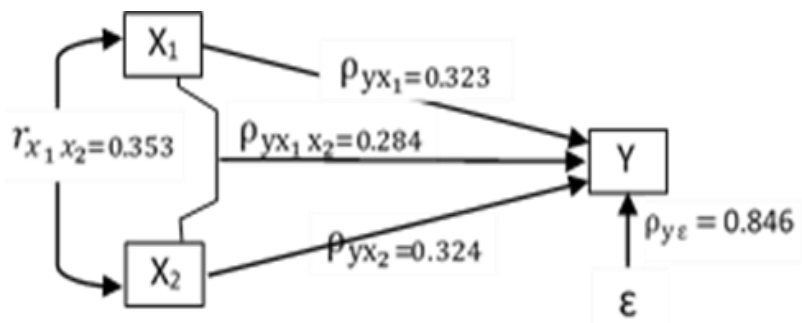

Gambar 4. Diagram Jalur Hasil Analaisis Path

Tabel 9. Hasil Uji Statistika Analisis Jalur X1 Dan X2 Terhadap Y

\begin{tabular}{|l|l|l|l|l|}
\hline $\begin{array}{l}\text { Paramet } \\
\text { er } \\
\text { Struktur } \\
\text { al }\end{array}$ & $\begin{array}{l}\text { Koefisi } \\
\text { en } \\
\text { Jalur }\end{array}$ & $\begin{array}{l}\text { t/f } \\
\text { Hitung }\end{array}$ & $\begin{array}{l}\text { t/f } \\
\text { Tabel }\end{array}$ & Keputusan \\
\hline$\rho_{y_{1}}$ & 0.323 & 2.397 & $\begin{array}{l}2.014 \\
1\end{array}$ & Menolak Ho \\
\hline$\rho_{y x_{z}}$ & 0.324 & 2.405 & $\begin{array}{l}2.014 \\
1\end{array}$ & Menolak Ho \\
\hline$\rho_{y x_{1} x_{z}}$ & 0,284 & 8.919 & 3.20 & Menolak Ho \\
\hline$\rho_{y \varepsilon}$ & 0.846 & & & \\
\hline
\end{tabular}

Sumber: Hasil analisis data dengan SPSS

\section{Besarnya pengaruh Variabel $\mathrm{X} 1$ dan $\mathrm{X} 2$ terhadap Y}

Pengaruh langsung X1 terhadap Y $(0.3232=0.104)$ atau $10.4 \%$ yang mengartikan bahwa secara langsung, sebesar 10.4\% peningkatan Kualitas Pelayanan Publik dipengaruhi oleh Etika Birokrasi tanpa melibatkan variabel lain.

Pengaruh tidak langsung X1 terhadap Y melalui X2 ( $0.323 \times 0.353 \times 0.324=0.036)$ atau $3.6 \%$ yang mengartikan bahwa secara tidak langsung sebesar $3.6 \%$ peningkatan Kualitas Pelayanan Publik bukan hanya dipengaruhi oleh Etika Birokrasi, tetapi melibatkan Kinerja Pegawai. 
Total pengaruh X1 terhadap Y $(0.104+$ $0.036=0.14$ ) atau $14 \%$.

Pengaruh langsung $\mathrm{X} 2$ terhadap $\mathrm{Y}$ $(0.3242=0.104)$ atau $10.4 \%$ yang mengartikan bahwa secara langsung sebesar 10.4\% peningkatan Kualitas Pelayanan Publik dipengaruhi oleh Kinerja Pegawai tanpa melibatkan variabel lain.

Pengaruh tidak langsung X2 terhadap $\mathrm{Y}$ melalui X1 (0.324 x $0.353 \times 0.323=0.036)$ atau $3.6 \%$ yang mengartikan bahwa secara tidak langsung sebesar $3.6 \%$ peningkatan Kualitas Pelayanan Publik bukan hanya dipengaruhi oleh Kinerja Pegawai melibatkan Etika Birokrasi.

Total pengaruh X2 terhadap Y $(0.104+$ $0.036=0.14$ ) atau $14 \%$

Total pengaruh terhadap $Y(0.14+0.14=$ 0.28 ) atau $28 \%$

Pengaruh Variabel lain terhadap $\mathrm{Y}$ $(0.8462=0.715)$.

Secara keseluruhan dapat dilihat pada tabel berikut:

Tabel 10. Besarnya Pengaruh Variabel X1 dan X2 terhadap $Y$

\begin{tabular}{|l|l|l|}
\hline $\begin{array}{l}\text { Pengaruh langsung X1 } \\
\text { terhadap Y }\end{array}$ & 0.104 & $\begin{array}{l}10.4 \\
\%\end{array}$ \\
\hline $\begin{array}{l}\text { Pengaruh tidak langsung X1 } \\
\text { terhadap Y melalui X2 }\end{array}$ & 0.036 & $3.6 \%$ \\
\hline Total pengaruh X1 terhadap Y & 0.14 & $14 \%$ \\
\hline $\begin{array}{l}\text { Pengaruh langsung X2 } \\
\text { terhadap Y }\end{array}$ & 0.104 & $\begin{array}{l}10.4 \\
\%\end{array}$ \\
\hline $\begin{array}{l}\text { Pengaruh tidak langsung X2 } \\
\text { terhadap Y melalui X1 }\end{array}$ & 0.036 & $3.6 \%$ \\
\hline Total pengaruh X2 terhadap Y & 0.14 & $14 \%$ \\
\hline Total pengaruh terhadap Y & 0.28 & $28 \%$ \\
\hline $\begin{array}{l}\text { Pengaruh Variabel lain } \\
\text { terhadap Y }\end{array}$ & 0.715 & $\begin{array}{l}71.5 \\
\%\end{array}$ \\
\hline
\end{tabular}

Sumber : Hasil analisis data, 2019

\section{Pengaruh Etika Birokrasi Terhadap Kualitas Pelayanan Publik}

Berdasarkan hasil pengujian

menunjukkan bahwa Etika Birokrasi berpengaruh terhadap Kualitas Pelayanan Publik Kantor Camat di Kota Bitung, pengaruh tersebut baik secara langusng maupun tidak langsung, (Darwin dalam Bisri \& Asmoro, 2019) mengartikan Etika Birokrasi sebagai seperangkat nilai yang menjadi acuan atau penuntun bagi tindakan manusia dalam organisasi publik. Dengan demikian dalam melaksanakan tugas sebagai pegewai negeri sipil, harus menaati segala niali-nilai dan aturan yang terkait dengan etika birokrasi, nilai-nilai dan aturan ini harus menjadi acuan dalam mengaplikasikan tugas dan tanggungjawab sebagai pelayan masyarakat karena akan memberi dampak pada kualitas pelayanan publik.

Hal ini sejalan dengan hasil penelitian (Pai, F.P. Pangkey, M.S. \& Tampi, 2016) bahwa penerapan Etika Birokrasi mempunyai pengaruh yang sangat nyata terhadap profesionalitas pelayan publik oleh aparatur birokrasi di Kantor Camat Malalayang Kota Manado. ini berarti bahwa perlunya pananaman Etika Birokrasi dalam peninkgatan Kualitas Pelayanan Publik bagi setiap pegawai. Perilaku yang baik dari sertiap pegawai dalam melayani masyarakat akan membuat masyarat tersebut merasa terlayani dengan baik, disi lain secara tidak langsung setiap pegawai ketika memiliki etika yang baik akan tergambar pada kinerjanya dan ini akan membuat semakin baiknya kualitas pelayanan kepada masyarakat.

\section{Pengaruh Kinerja Pegawai Terhadap Kualitas Pelayanan Publik}

Berdasarkan hasil pengujian menunjukkan bahwa Kinerja Pegawai memiliki pengaruh terhadap Kualitas Pelayanan Publik Kantor Camat di Kota Bitung baik secara langsung maupun tidak langsung. (Sinambela dalam Sasti, E.W. Samin, R. \& Noryadi, 2015) mendefinisikan "Kinerja Pegawai sebagai kemampuan pegawai dalam melakukan sesuatu dengan keahlian tertentu. Setiap pegawai terntu harus memiliki kemampuan dan keahlian dalam menyelesaikan pekerjaan dengan memiliki kemampuan dan keahlian yang baik, maka akan meningkatkan kualitas kinerja dari pegawai tersebut dan akan memberi dampak dalam peningkatan kualitas pelayanan publik. (Djabbar \& Baso, 2019) menyatakan bahwa kinerja yang baik adalah kinerja yang mengikuti tata cara atau prosedur sesuai standar yang telah ditetapkan. Akan tetapi didalam kinerja tersebut mesti harus memiliki beberapa kriteria agar meningkatnya produktiitas sehingga apa yang diharapkan tersebut biasa berjalan sesuai apa yang di inginkan 
Hal ini sejalan dengan penelitian (Supit, T.J. Tampi, J.R. \& Londa, 2015) yang menyatakan bahwa Kinerja Pegawai berpengaruh terhadap kualitas pelayanan Di Perusahaan Daerah Air Minum Kota Tomohon, dimana dalam penelititannya Kinerja Pegawai ditinjau dari beberapa aspek yaitu Kuantitas, Kualitas, Waktu, Biaya, Tempat dan Ruang. Hal ini menunjukan bahwa setiap pegawai harus menunjukan kinerja yang baik sehingga akan berdampak pada hasil pekerjaannya, ketika masyarakat puas terhadap pelayanan yang dilakukan para pegawai, maka dengan demikian menggambarkan hasil kinerja dari pegawai tersebut. Secara tidak langsung baik tidaknya Kinerja Pegawai terlihat dari pemahaman para pegawai terhadap Etika Birokrasi, kinerja yang baik dari setiap pegawai terimplementasi dari perilaku pegawai tersebut dan itu akan berdampak pada pelayanan kepada masyarkaat

\section{Pengaruh Etika Birokrasi dan Kinerja Pegawai Terhadap Kualitas Pelayanan Publik}

Berdasarkan hasil pengujian menunjukkan bahwa Etika Birokrasi dan Kinerja Pegawai secara bersama-sama berpengaruh terhadap Kualitas Pelayanan Publik Kantor Camat di Kota Bitung. Hal ini didukung oleh pendapat (Berry dalam Pasolong, 2011) untuk mengetahui kualitas pelayanan yang dirasakan secara nyata oleh konsumen, ada indikator ukuran kepuasan konsumen yang terletak pada lima dimensi kualitas pelayanan yaitu:

1. Tangibles, kualitas pelayanan berupa sarana fisik perkantoran, kpmputerisasi administrasi, ruang tunggu, tempat informasi.

2. Reliability, kemampuan dan keandalan untuk menyediakan pelayanan yang terpercaya

3. Responsivess, kesanggupan untuk membantu dan menyediakan pelayanan secara cepat dan tepat, seta tanggap terhadap keinginan konsumen.

\section{SIMPULAN}

Berdasarkan hasil dan pembahasan, maka simpulan dalam penelitian adalah Etika Birokrasi berpengaruh secara langsung sebesar $0.104(10.4 \%)$ dan secara tidak langsung sebesar $0.036 \quad$ (3.6\%) terhadap Kualitas Pelayanan Publik, Kinerja Pegawai berpengaruh secara langsung sebesar 0.104 (10.4\%) dan secara tidak langsung sebesar 0.036 (3.6\%) terhadap Kualitas Pelayanan Publik, dan secara bersama-sama Etika Birokrasi dan Kinerja Pegawai berpengaruh terhadap Kualitas Pelayanan Publik, itu dibuktikan dengan hasil pengujian simultas, dimana f hitung $8.919>\mathrm{f}$ tabel 3.20, dengan nilai signivikasi $0.001<\alpha=0.05$

\section{DAFTAR PUSTAKA}

Bisri, M. H., \& Asmoro, B. T. (2019). Etika Pelayanan Publik di Indonesia. Journal of Governance Innovation, 1(1), 59-76. https://doi.org/10.36636/jogiv.v1i1.298

Djabbar, I., \& Baso, S. (2019). Pengembangan Usaha Kecil \& Menengah (UKM) Di Kabupaten Kolaka Utara. Publikauma : Jurnal Administrasi Publik Universitas Medan Area, $7(2)$, 116. https://doi.org/10.31289/publika.v7i2.2974

Margono. (2004). Metodologi Penelitian Pendidikan. Jakarta: Rineka Cipta.

Pai, F.P. Pangkey, M.S. \& Tampi, G. . (2016). PELAYANAN PUBLIK DI KANTOR CAMAT MALALAYANG KOTA MANADO Faisal Putra Pai Masje Pangkey. Jurnal Administrasi Publik, 1(36), 1-11.

Pasolong, H. (2011). Teori Administrasi Publik. Bandung: Alfabeta.

Sasti, E.W. Samin, R. \& Noryadi, E. (2015). Pengaruh Kinerja Pegawai terhadap Kualitas Pelayanan Publik pada kantor camat kundur kabupaten karimun (Universitas Maritim Raja Ali). Retrieved from http://jurnal.umrah.ac.id/?p=3479

Sinambela, L. . (2011). Reformasi Pelayanan Publik. Jakarta: Bumi Akasara.

Sugiono. (2001). Statistika untuk Penelitian. Bandung: Alfabeta.

Sugiono. (2016). Metode Penelitian Kuantitatif, Kualitatif dan R\&D. Bandung: Alfabeta.

Supit, T.J. Tampi, J.R. \& Londa, V. . (2015). Pengaruh Kinerja Pegawai Terhadap Kualitas Pelayanan Di Perusahaan Daerah Air Minum 
Michel J.N. Potola, Pengaruh Etika Birokrasi dan Kinerja Pegawai Terhadap Kualitas Pelayanan Publik

Kota Tomohon. Jurnal Ilmu Sosial \& Pengelolaan Sumberdaya Pembangunan, 1(17), 1-15.

Susanti, A., Kusmanto, H., \& Tarigan, U. (2018). Implementasi Kebijakan Pelayanan Administrasi Terpadu Kecamatan (PATEN) Terhadap Kualitas Pelayanan Publik Di Kecamatan Sidikalang Kabupaten Dairi. Publikauma: Jurnal Administrasi Publik Universitas Medan Area, 6(1), 47-57. 